\title{
Investing with Prejudice: The Relationship Between Women's Presence on Company Boards and Objective and Subjective Measures of Company Performance
}

\author{
S. Alexander Haslam, ${ }^{1}$ Michelle K. Ryan, ${ }^{1}$ Clara Kulich,${ }^{2}$ Grzegorz \\ Trojanowski ${ }^{2}$ and Cate Atkins ${ }^{1}$ \\ ${ }^{1}$ School of Psychology, University of Exeter, Exeter EX4 4QG, UK, and \\ ${ }^{2}$ University of Exeter Business School, Exeter EX4 4QG, UK \\ Email: A.Haslam@exeter.ac.uk; M.Ryan@exeter.ac.uk; C.Kulich@exeter.ac.uk; \\ G.Trojanowski@exeter.ac.uk; Cate.Atkins@exeter.ac.uk
}

\begin{abstract}
This paper presents a comprehensive archival examination of FTSE 100 companies in the period 2001-2005, focusing on the relationship between the presence of women on company boards and both accountancy-based and stock-based measures of company performance. Consistent with work by Adams, Gupta and Leeth this analysis reveals that there was no relationship between women's presence on boards and 'objective' accountancy-based measures of performance (return on assets, return on equity). However, consistent with 'glass cliff' research there was a negative relationship between women's presence on boards and 'subjective' stock-based measures of performance. Companies with male-only boards enjoyed a valuation premium of $37 \%$ relative to firms with a woman on their board. Results support claims that women are found on the boards of companies that are perceived to be performing poorly and that their presence on boards can lead to the devaluation of companies by investors. Yet the findings also indicate that perceptions and investment are not aligned with the underlying realities of company performance.
\end{abstract}

\section{Introduction}

In recent years there has been considerable debate both about the circumstances in which women are appointed to leadership positions and about the consequences of these appointments. In

\footnotetext{
Versions of this paper were presented at the Canadian Institute for Advanced Research in Vancouver on 9 March 2008 and at the Academy of Management Annual Meeting in Chicago, 7-11 August 2009. We would like to thank George Akerlof, Roland Bénabou, Pierre Fortin, John Helliwell, Rachel Kranton and several anonymous reviewers for their comments. This research was supported by a grant from the Economic and Social Research Council (RES-062-23-0135).
}

the British context, this debate was initially fuelled by evidence (collected in 2003) that where women had been appointed to the boards of the top 100 companies listed on the London Stock Exchange (i.e. the constituents of the Financial Times FTSE 100 index), those companies had also suffered from poor stock-market performance. Specifically, companies at the very top of the Female FTSE Index (the FFI, which ranks FTSE 100 companies in terms of the number of women on their boards) (Singh and Vinnicombe, 2003) were found by Judge (2003) to be towards the bottom of tables ranking them in terms of share performance. On this basis, Judge authored a lead business story in The Times in which she 
concluded that 'the triumphant march of women into the country's boardrooms has ... wreaked havoc on companies' performance and share prices' (2003, p. 21).

This conclusion, however, was subsequently challenged by a more thoroughgoing archival examination of the same 2003 FTSE data that was subsequently reported in the British Journal of Management $(B J M)$. Specifically, Ryan and Haslam (2005) attempted to shed light on the causal underpinnings of the correlation identified by Judge (2003) by looking at company performance in the months before and after the appointment of a matched sample of men and women to the boards of UK companies. From this analysis it was apparent that, during a period of stock-market decline, companies which appointed women to their boards were more likely to have experienced consistently poor month-onmonth stock-market performance in the period preceding the appointment than companies which appointed men. However, in the threemonth period after appointments had been made, this difference was attenuated and the stock returns for companies which had appointed women were no different from those which had appointed men.

On this basis, Ryan and Haslam argued that, rather than women's appointment to leadership positions causing poor company performance, poor performance appeared to have led to the appointment of women to leadership positions. The researchers also saw this particular pattern as indicative of a more widespread tendency for women who break through the 'glass ceiling' to find themselves in leadership positions that are risky and precarious because they are associated with organizational units that are in crisis. Extending the metaphor of the glass ceiling, Ryan and Haslam (2005, 2007) characterize this predicament as being atop a 'glass cliff' whereby women are elevated but dangerously exposed.

Further support for the existence of glass cliffs has been garnered from qualitative and quantitative research which delves more deeply into the dynamics surrounding women's experiences of leadership. In particular, the tendency to prefer women over men for leadership positions in organizations that are in crisis has been confirmed by studies in which organizational fortunes are experimentally manipulated. A consistent finding in this research is that women are selected for leadership positions ahead of similarly qualified men when (and only when) there is a high risk of organizational failure (Haslam and Ryan, 2008; see also Ashby, Ryan and Haslam, 2007; Bruckmüller and Branscombe, 2007).

More recently, though, the idea that women are selectively recruited for leadership positions in organizations that are failing has been challenged by more extensive archival investigation. In this research (which was also published in $B J M)$, Adams, Gupta and Leeth (2009) examined companies' financial performance leading up to and following the appointment of CEOs in the USA over a 12-year period. This analysis centred on three key indicators of performance - return on assets (ROA), return on equity (ROE) and earnings per share - and found no reliable evidence of difference in companies' performance before or after the appointment of women and men. On this basis, the authors question the universality of the glass cliff and conclude that CEO hiring practices 'are not gender biased' (p. 11).

As Ryan and Haslam (2009) note, there are of course many differences between the archival studies of Ryan and Haslam (2005) and Adams, Gupta and Leeth (2009) that might account for the different patterns they reveal - most obviously, the fact that they were conducted in different countries (with different economies and culture) and in relation to positions of different seniority. ${ }^{1}$ Beyond these, though, one difference which may be of particular theoretical and practical significance is that, whereas Ryan and Haslam's study (like Judge's (2003) article before it) speaks exclusively to the 'subjective' data surrounding investor perceptions and behaviour, Adams, Gupta and Leeth's speaks much more to the 'objective' accounting-based realities of actual financial performance (e.g. as measured by ROA and ROE). This distinction between

\footnotetext{
${ }^{1}$ The possibility that level of appointment may be a relevant factor emerges from US data presented by Lee and James (2007). These indicated that company performance (measured as net income divided by sales in the year before the announcement) was worse prior to the appointment of a female top management team member than a male top management team member ( 0.98 versus -0.14$)$, but better prior to the appointment of a female CEO than a male CEO (0.01 versus -1.40$)$.
} 
accounting-based and stock-based measures is one that researchers have previously identified as significant (e.g. Bushman and Indjejikian, 1993; Kim and Suh, 1993) and it is potentially important in the present context since the factors that relate to the creation and existence of glass cliffs may be more (social) psychological than economic - relating to the subjective dynamics of prejudice and sexism rather than simply those of objective financial fact (Devers et al., 2007). Indeed, the idea that perceptions do not correspond to reality lies at the heart of most claims of prejudice, discrimination and bias (Allport, 1954; Oakes, Haslam and Turner, 1994).

Amongst other things, then, the work of Ryan and Haslam (2007) draws attention to the role played by a number of well-documented psychological factors in the appointment of women to particular leadership positions and in the treatment they receive once in those positions. These include (a) gender stereotypes about competence and leadership ability (Eagly and Karau, 2002; Kulich, Ryan and Haslam, 2007; Schein, 1973), (b) expectations about career trajectories (Haslam and Ryan, 2008; Stroh, Brett and Reilly, 1996), (c) gender-specific judgements about the suitability of particular roles for men and women (e.g. Eagly, Johannesen-Schmidt and van Engen, 2003; Powell and Butterfield, 1994; Ryan et al., 2009) and (d) dynamics of prejudice and discrimination (e.g. Branscombe, 1998; Ellemers et al., 2004; Schmitt, Branscombe and Postmes, 2003).

Speaking further to the significance of these 'subjective' factors in the context of women's appointment to high-profile leadership roles, evidence drawn from a very similar sample to that studied by Adams, Gupta and Leeth (2009) indicates that investors respond differently to the appointment of male and female CEOs. Specifically, Lee and James (2007) examined stockmarket responses to the appointment of CEOs in the USA between 1990 and 2000 and found that these reactions were much more negative (as indicated by lower cumulative abnormal returns) when the new CEO was female rather than male. The authors attribute this to the increased levels of scrutiny and scepticism that are aroused by women's appointment to senior positions. This reaction is associated with women's status as 'tokens' (Kanter, 1977) and is akin to that provoked by the arrival of any 'outsider'.
Moreover, while there is evidence that stakeholders' reactions to the appointment of women to company boards varies as a function of contextual factors (e.g. a company's cultural milieu, strategic focus and consumer orientation) (Brammer, Millington and Pavelin, 2009; Campbell and Minguez-Vera, 2008; Dwyer, Richard and Chadwick, 2003), it is also possible that the appointment of a woman to a senior position is interpreted by investors as a signal of organizational difficulties or decline (in line with signalling theory) (Higgins and Gulati, 2006; Trevis Certo, 2003). Indeed, if women tend to be appointed in times of crisis (as glass cliff research suggests), then there may be good reason why investors and commentators like Judge (2003) regard their appointment as an ominous portent. Yet whatever the reasons for the unenthusiastic reception that greets new women leaders, Lee and James's research makes the point that the circumstances surrounding the appointments of men and women to senior company positions are not straightforwardly equivalent in ways that Adams, Gupta and Leeth's (2009) data might imply.

\section{The present study}

In light of the above review, there is still clearly a pressing need for research that could help to explain the inconsistent findings observed across previous studies of the relationship between the appointment of women to senior leadership positions and company performance. Speaking to this need, the aim of the present study was to conduct a comprehensive archival examination that broadened the base of Ryan and Haslam's (2005) study (and that of Judge, 2003) in a number of ways. First, it did this by including performance data between the years 2001 and 2005 for all FTSE 100 companies for which full data sets were available in any of these five years. This time period is particularly significant in the context of the present debate as it saw a marked increase in the representation of women on the boards of UK companies (among FTSE 100 companies it increased from $56.6 \%$ in 2001 to $78.4 \%$ in 2005 ; Singh and Vinnicombe (2005); see below). As a result, this period was also characterized by considerable discussion of the impact of women's appointment to senior positions. 
As noted above, much of the previous work in this area has focused specifically on the appointment of women to leadership roles (e.g. Haslam and Ryan, 2008; Ryan and Haslam, 2005) and also concentrated on those who are in CEO positions (e.g. Adams, Gupta and Leeth, 2009; Lee and James, 2007). In contrast, the focus of the present study was broadened to look at women's presence on company boards. It is nevertheless the case that the data we examine are directly relevant to the glass cliff phenomenon because this relates to the tendency for women to be selected for, and hence subsequently to be found in, precarious leadership positions (Ryan and Haslam, 2007). Accordingly, while the phenomenon relates both to CEOs and to leadership appointments, it is not restricted to either. As an aside, it is also worth remarking that had this study been confined to an analysis of the appointments of CEOs to FTSE 100 companies, then for the period under investigation it would have included only two women and hence been unviable.

A third way in which the study went beyond previous research was by including both accounting-based and stock-based measures of company performance. In line with distinctions noted above, the former speak to the 'objective' financial realities of ROE and ROA (the focus of Adams, Gupta and Leeth's (2009) analysis), while the latter relate to 'subjective' investor perceptions and behaviour (the focus of work by Judge, 2003; Lee and James, 2007; Ryan and Haslam, 2005). Although both types of measure provide some insight into company performance, both are acknowledged to have particular strengths and weaknesses. In this respect, one difference is that accounting-based measures (e.g. ROA, ROE; see Table 1) are relatively backward-looking (i.e. based on assessment of how the company has performed in the recent past), while stock-based measures (e.g. Tobin's Q) are relatively forward-looking - in the sense that they not only reflect a company's current position but also its potential to be successful in the future (Devers et al., 2007). A second, related, difference is that accounting measures are based on self-reported company data that are compiled in accordance with prevailing (legally enforceable) accounting principles that are intended to prevent distortion and manipulation of relevant financial information. On the other hand, stock-based measures are heavily influenced by
Table 1. Formulae for calculations of company performance measures

\begin{tabular}{|c|c|c|}
\hline $\begin{array}{l}\text { Performance } \\
\text { measure }\end{array}$ & $\begin{array}{l}\text { Type of } \\
\text { measure }\end{array}$ & Calculation \\
\hline ROA & $\begin{array}{l}\text { Accounting- } \\
\text { based }\end{array}$ & $\begin{array}{l}\text { (earnings before extraordinary } \\
\text { income and preferred dividend in } \\
\text { financial year } \mathrm{t} \text { )/(average of book } \\
\text { values of total assets at the } \\
\text { beginning and at the end of } \\
\text { financial year } \mathrm{t} \text { ) }\end{array}$ \\
\hline ROE & $\begin{array}{l}\text { Accounting- } \\
\text { based }\end{array}$ & $\begin{array}{l}\text { (earnings before extraordinary } \\
\text { income and preferred dividend in } \\
\text { financial year } \mathrm{t} \text { )/(average of book } \\
\text { values of common equity at the } \\
\text { beginning and at the end of } \\
\text { financial year } \mathrm{t} \text { ) }\end{array}$ \\
\hline Tobin's Q & Stock-based & $\begin{array}{l}\text { (year end market } \\
\text { capitalization + average of book } \\
\text { values of total debt at the beginning } \\
\text { and at the end of financial year } \mathrm{t} \text { ) } \\
\text { (average of book values of total } \\
\text { assets at the beginning and at the } \\
\text { end of financial year } \mathrm{t} \text { ) }\end{array}$ \\
\hline
\end{tabular}

market reactions that reflect investor perceptions and behaviour (Fama, 1991). Amongst other things, these are shaped by (a) market sentiment (in particular, confidence; Akerlof and Shiller, 2009; Barberis and Thaler, 2003), (b) behaviour and beliefs of other investors (see Keynes, 1936) and (c) analysts' views about a company's prospects (Dechow and Sloan, 1997). Although the activities of the company can be important here, these perceptions are often well beyond the company's control.

On the basis of previous research and arguments about the potential significance of this distinction between 'objective' and 'subjective' measures, our main hypotheses were as follows.

H1: That there would be no relationship between women's presence on company boards and accountancy-based company performance (as assessed by ROA and ROE; in line with Adams, Gupta and Leeth, 2009).

H2: That there would be a negative correlation between women's presence on company boards and a stock-based measure of company performance (as assessed by Tobin's Q; in line with Judge, 2003; Lee and James, 2007; Ryan and Haslam, 2005).

A further advantage of the present study's design was that the inclusion of multiple measures of 
performance at multiple points in time meant that if and where there was evidence of a relationship between women's presence on company boards and company performance, it was also possible to examine time-lagged correlations (Granger, 1969; Zellner, 1979) to test two further hypotheses.

H3: That the presence of women on company boards is preceded by poor company performance (in line with the 'glass cliff' hypothesis; Ryan and Haslam, 2005).

H4: That the presence of women on company boards presages poor company performance (in line with Judge (2003) for accountancy-based measures; Lee and James (2007) for stockbased measures).

It is worth noting that although these hypotheses are in some sense competitive, as aspects of an ongoing dynamic both could nevertheless be supported simultaneously.

\section{Method}

\section{Sample}

Analysis was based on an examination of annual records for all FTSE 100 companies between 2001 (the year in which Singh and Vinnicombe first compiled the FFI) and 2005 (the last year for which full data sets were available at the time the research was conducted). From these records we abstracted data relating to both board composition and company performance, in order to test the above hypotheses. No existing data set contained all the information in which we were interested, and so data had to be drawn from multiple sources (e.g. the FFI, the Thomson ONE Banker database) specifically for this purpose.
For this reason, it was not possible to obtain complete data sets for all companies in all years. However, the final sample was very nearly complete, including full data from 92 companies in 2001, 96 in 2002, 90 in 2003, 88 in 2004 and 92 in $2005(\mathrm{M}=91.6 \%)$. The resultant database included data from 126 companies that were included in the FTSE 100 index in at least one of the five years in which we were interested. Seventy of these companies $(49.6 \%)$ were included in the sample for all five years, $14(9.9 \%)$ were included for four of the five years, ten $(7.1 \%)$ for three of the five years, $13(9.2 \%)$ for two of the five years, and $19(13.5 \%)$ for just one of the five years.

\section{Measures}

Board composition. For all FTSE 100 companies for which full performance data were available, and for each of the five years of the study, we used the FFI (e.g. Singh and Vinnicombe, 2003) to ascertain (a) the number of women who were full members of the company's board of directors and (b) the total number of full board members. From these data it was possible to compute several further measures: (c) whether or not the board had any women on it and (d) the percentage of board members who were female. Relevant data are presented in Table 2.

Company characteristics. For purposes of subsequent statistical control, a range of company characteristics were identified and recorded. These included the size of the board and the number of employees (measures which can both be seen as indicators of company size) (Boone et al., 2007; Burke, 2000), as well as the nature of the company's business (categorized by industry sector following the GICS Classification Guide, as recommended by Bhojraj, Lee and Oler, 2003;

Table 2. Board gender composition as a function of year

\begin{tabular}{lcccccc}
\hline Measure & \multicolumn{3}{c}{ Year } \\
\cline { 2 - 7 } & 2001 & 2002 & 2003 & 2004 & 2005 & F value \\
\hline $\mathrm{N}$ & 99 & 100 & 95 & 95 & 97 & 1.23 \\
Mean number of women on board & 0.75 & 0.84 & 1.02 & 1.12 & $4.44^{* *}$ \\
Percentage of companies with women on board & 56.6 & 61.0 & 67.4 & 68.4 & 78.4 & $3.04 *$ \\
Mean percentage of board members who are women & 6.5 & 7.2 & 8.7 & 9.6 & 10.5 & $4.65^{* *}$ \\
\hline
\end{tabular}

$* * \mathrm{p}<0.01 ; * \mathrm{p}<0.05$. 
Chan, Lakonishok and Swaminathan, 2007). In the latter case, industry sector was coded to reflect whether or not a company was (a) a financial company (since this has a bearing on the accounting practices that the company uses) and (b) stereotypically feminine. The latter variable was assessed by asking two independent coders to rate each of the 260 business sectors defined by the GICS Classification Guide as either stereotypically feminine (1; e.g. retail, hospitality, health care) or not (0; e.g. mining, banking, IT). These coders agreed on $98.5 \%$ of categorizations, and those on which they disagreed $(n=4)$ were resolved through discussion.

Company performance. As suggested in the Introduction, the existing management literature includes a number of measures which stress distinct dimensions of company outcomes (Tosi et al., 2000). In particular, a distinction is made between two main categories of measure: accounting-based and stock-based (e.g. Bushman and Indjejikian, 1993; Kim and Suh, 1993). The accounting-based measures used in the present study reflect the profitability of the company in a given year. Here two different measures were obtained (as previously employed by Adams, Gupta and Leech, 2009): (a) ROA and (b) ROE. The nature of these measures is summarized in Table 1, and use of both measures assures some robustness of conclusions and mitigates against the possibility that observed patterns of performance are simply a reflection of the company's capital structure.

The stock-based measure of company performance used in this study is also one that has consistently been used in previous research: Tobin's Q (see for example Demsetz and Lehn, 1985; Gompers, Ishii and Metrick, 2003; Morck, Shleifer and Vishny, 1988). This measure was developed by Tobin (1969) and compares the market value of a company with the replacement value of a company's assets. In our analysis, we follow Kaplan and Zingales (1997) in calculating Tobin's $\mathrm{Q}$ as the ratio of the sum of market capitalization and book value of debt to the book value of total assets (i.e. so that the book value of total assets proxies for their replacement value). In this way, Tobin's Q is an estimate of how efficient investors perceive a company's use of its assets to be.

\section{Results}

\section{Board composition}

Analysis of variance (ANOVA) was conducted to examine changes in the gender composition of company boards over time. ${ }^{2}$ Results are presented in Table 2. From this it can be seen that between 2001 and 2005 there was a substantial increase (a) in the mean number of women on company boards (from 0.75 per board in 2001 to 1.23 per board in $2005 ; \mathrm{F}(4,481)=4.44$, $\mathrm{p}=0.002$ ), (b) in the percentage of companies that had a woman on their board (from $56.6 \%$ in 2001 to $78.4 \%$ in $2005 ; \mathrm{F}(4,481)=3.04$, $\mathrm{p}=0.017$ ) and (c) in the mean percentage of board members that were women (from $6.5 \%$ in 2001 to $10.5 \%$ in $2005 ; \mathrm{F}(4,481)=4.65$, $\mathrm{p}=0.001)$.

\section{Control variables}

Bivariate correlations were examined to see if there was a relationship between the presence of women on company boards (the percentage of board members who were women; whether or not the board had a woman on it) and either the size of the company (as indicated by the size of the board and the number of employees) or business type (financial company, 'feminine' company). Correlations are presented in Table 3. From this it can be seen that there was no relationship between the gender composition of a company's board and the company having either a large board or being in the financial sector. Interestingly, though, there was evidence that a board's gender composition was correlated with (a) the company's business being stereotypically feminine (this was correlated with the percentage of board members who were women, $\mathrm{r}=0.12$, $\mathrm{p}=0.01$ ) and (b) the number of company employees (this was correlated with both the percentage of board members who were women

\footnotetext{
${ }^{2}$ This analysis treats year as a between-companies variable. However, observations across years are not independent and hence it would be more appropriate to treat year as a within-companies measure. Yet because the composition of the FTSE 100 varies across years, this strategy would reduce the overall sample size considerably. Moreover, when this strategy is adopted it changes neither the pattern of the results nor their significance.
} 
Table 3. Bivariate correlations between measures of board gender composition and control variables

\begin{tabular}{lcccccc}
\hline & Mean & $\begin{array}{c}\text { Woman on } \\
\text { board }(\mathrm{Y} / \mathrm{N})\end{array}$ & $\begin{array}{c}\text { Size of } \\
\text { board }\end{array}$ & $\begin{array}{c}\text { No. of } \\
\text { employees }\end{array}$ & $\begin{array}{c}\text { Financial } \\
\text { company }\end{array}$ & $\begin{array}{c}\text { 'Feminine' } \\
\text { business }\end{array}$ \\
\hline \% of women board members & 8.44 & $0.78^{* *}$ & 0.03 & $0.15^{* *}$ & 0.07 & $0.12^{* *}$ \\
Woman on board (Y/N) & 0.77 & & 0.07 & $0.11^{* *}$ & 0.04 & 0.04 \\
Size of board & 11.30 & & & $0.26^{* *}$ & -0.07 & -0.01 \\
No. of employees & 40,679 & & & & $-0.12^{* *}$ \\
Financial company & 0.18 & & & & \\
'Feminine' business & 0.10 & & & & \\
\hline
\end{tabular}

$* * \mathrm{p}<0.01 ; \mathrm{p}<0.05$.

Table 4. Bivariate correlations between measures of board gender composition and company performance

\begin{tabular}{|c|c|c|c|c|c|}
\hline & $\begin{array}{l}\text { Woman on } \\
\text { board }(\mathrm{Y} / \mathrm{N})\end{array}$ & Year & ROE & ROA & Tobin's Q \\
\hline$\%$ of board members who are women & $0.78^{* *}$ & $0.19 * *$ & 0.03 & 0.04 & $-0.11^{*}$ \\
\hline Woman on board $(\mathrm{Y} / \mathrm{N})$ & & $0.13^{* *}$ & 0.04 & -0.02 & $-0.16^{* *}$ \\
\hline Year (2001-2005) & & & 0.08 & $0.14 * *$ & -0.06 \\
\hline ROE & & & & $0.18^{* *}$ & 0.01 \\
\hline ROA & & & & & $0.41^{* *}$ \\
\hline
\end{tabular}

$* * \mathrm{p}<0.01 ;{ }^{*} \mathrm{p}<0.05$.

$(\mathrm{r}=0.11, \mathrm{p}=0.01)$ and the presence of a woman on the board $(\mathrm{r}=0.15, \mathrm{p}=0.001))$.

This suggests that the latter variables (company gender stereotypicality and number of employees) need to be controlled for in our analysis of the relationship between board gender composition and company performance. Nevertheless, regression analysis indicated that, when controls of this form were included, they had a negligible (and non-significant) bearing on the results we report below. Yet because it was generally less related to potential contaminating factors, in the analysis that follows we use the presence of women on company boards (i.e. whether boards were all-male or had at least one woman on them) as our primary measure of board gender composition.

\section{Company performance}

The relationship between company performance and women's presence on company boards ( $\mathrm{Hy}$ potheses 1 and 2). As with control variables, a first phase of analysis involved examining bivariate correlations to see if there was a relationship between the gender composition of company boards and either accountancy-based (ROA, ROE) or stock-based (Tobin's Q) measures of company performance. Correlations are presented in Table 4. From this it can be seen that, consistent with Hypothesis 1, within the data set as a whole there was no relationship between the presence or the percentage of women on company boards and either ROA or ROE $(-0.02<\mathrm{r}<0.04$, all $\mathrm{p}>0.35)$. However, consistent with Hypothesis 2, there was a significant negative correlation between both the presence and the percentage of women on company boards and Tobin's $\mathrm{Q}(\mathrm{r}=-0.16,-0.11$; $\mathrm{p}=0.001,0.02$, respectively).

To examine this effect further, ANOVA was conducted to examine stock-based performance (Tobin's Q) as a function of board composition (all-male versus at least one woman member) and year (2001-2005). Figure 1 presents these data graphically. From this it can be seen that there was a main effect for board composition such that companies with at least one woman on their board had lower values of Tobin's $Q$ than those with all-male boards $(\mathrm{M}=1.66,1.21$, respectively; $\mathrm{F}(1,458)=10.47 ; \mathrm{p}<0.001)$. In other words, companies with male-only boards were valued at $166 \%$ of the book value of their assets, while those with at least one female on board were valued at $121 \%$ of their book values. In stark terms, this indicates that companies with 


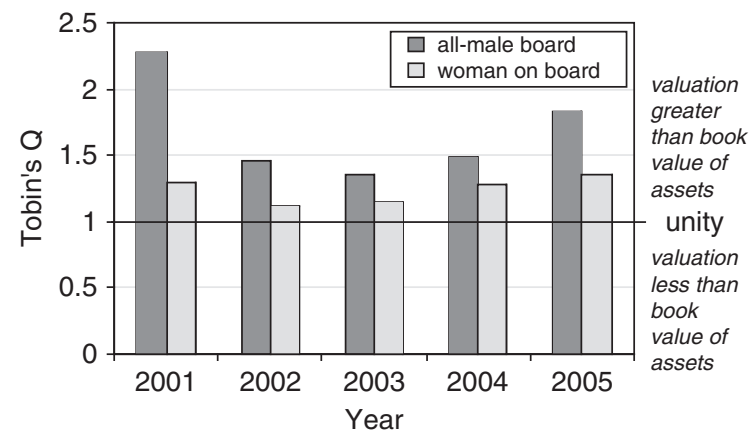

Figure 1. Tobin's $Q$ as a function of year and women's presence on company boards

male-only boards enjoyed a valuation premium of $37 \%$ (i.e. $(1.66-1.21) / 1.21=0.37)$ over otherwise similar firms with one or more women on the board. The main effect for year and the interaction between year and board composition were both non-significant $(\mathrm{F}(4,458)=2.32,1.24$, $\mathrm{p}=0.06,0.29$, respectively).

Although the foregoing analyses are useful for exploratory purposes, one problem with them is that they treat observations across years as independent when they are not (see footnote 2 earlier). Although this practice is not uncommon, it means that the analyses involve a certain amount of over-counting or 'double-dipping' which artificially inflates statistical significance. One way to address this issue and to get a more realistic assessment of effect size (Cohen, 1977) and consistency is to examine data for each year separately. To this end, independent $t$ tests were conducted to examine year-by-year differences in Tobin's Q as a function of board composition (all-male versus at least one woman member). These indicated that companies with all-male boards had significantly higher Tobin's Q than those with at least one woman on them in $2001(\mathrm{M}=2.27,1.28$, respectively, $\mathrm{t}(90)=2.05$, $\mathrm{p}=0.04, \mathrm{~d}=0.43)$ and $2005(\mathrm{M}=1.82,1.28$, respectively, $\mathrm{t}(90)=1.97, \mathrm{p}=0.05, \mathrm{~d}=0.41)$, but that, although in the direction predicted by Hypothesis 2, this difference was non-significant in $2002(\mathrm{M}=1.42,1.12$, respectively, $\mathrm{t}(94)=1.51$, $\mathrm{p}=0.13, \mathrm{~d}=0.31), 2003(\mathrm{M}=1.34,1.16$, respectively, $\mathrm{t}(88)=0.74, \mathrm{p}=0.46, \mathrm{~d}=0.16)$ and 2004 $(\mathrm{M}=1.45, \quad 1.20, \quad$ respectively, $\mathrm{t}(86)=1.10$, $\mathrm{p}=0.28, \mathrm{~d}=0.24)$. Overall, then, the relationship between the presence of women on company boards and Tobin's $Q$ was of variable significance but always negatively signed and of small to medium size (by Cohen's (1977) criteria; mean $\mathrm{d}=0.31$ ). At the level of individual companyyears, this evidence is thus generally consistent with the pattern that emerges from the aggregated analysis reported above.

The time-lagged relationship between stock-based measures of company performance and women's presence on company boards (Hypotheses 3 and 4). Having established support for Hypothesis 2 with respect to a stock-based measure of performance (Tobin's Q), it is possible to examine the relationship between this measure of performance and board gender composition more closely in an attempt to shed light on issues of causality. Specifically, following the logic of tests developed by Granger (1969) (see also Zellner, 1979) we can examine time-lagged correlations between board composition and Tobin's Q to assess the evidence (a) that Tobin's $\mathrm{Q}$ in one particular year predicts board composition in subsequent years (Hypothesis 3) and (b) that board composition in one particular year predicts Tobin's Q in subsequent years (Hypothesis 4). Correlations pertaining to these hypotheses are presented in Table 5. Consistent with both Hypothesis 3 and Hypothesis 4, it can be seen that all the correlations in this table are negatively signed. In line with Hypothesis 3 , as a group, those correlations above the diagonal differ significantly from $0(\mathrm{~F}(3,283)=4.64$, $\mathrm{p}=0.01)$. In line with Hypothesis 4, as a group, those correlations below the diagonal also differ significantly from $0(\mathrm{~F}(3,325)=6.45, \mathrm{p}=0.002)$.

Table 5. Time-lagged correlations between women's presence on company boards and Tobin's $Q$

\begin{tabular}{rccccc}
\hline & \multicolumn{5}{c}{ Woman on board (Y/N) } \\
\cline { 2 - 6 } & 2001 & 2002 & 2003 & 2004 & 2005 \\
\hline Tobin's Q 2001 & $-0.21^{*}$ & -0.06 & -0.14 & -0.16 & -0.07 \\
2002 & $-\mathbf{0 . 2 3}^{*}$ & -0.07 & -0.08 & -0.08 & -0.09 \\
2003 & $-\mathbf{0 . 2 6}^{*}$ & $-\mathbf{0 . 0 8}$ & -0.08 & -0.08 & -0.07 \\
2004 & $-\mathbf{0 . 2 8}$ & $-\mathbf{0 . 1 2}$ & $-\mathbf{0 . 1 1}$ & -0.12 & -0.05 \\
2005 & $-\mathbf{0 . 3 6}$ & $-\mathbf{0 . 1 9}$ & $-\mathbf{0 . 2 3}$ & $-\mathbf{0 . 2 4} *$ & $-0.21^{*}$ \\
\hline
\end{tabular}

Notes: Correlations in italics (above the diagonal) pertain to the potential impact of Tobin's Q on the likelihood of subsequently having a woman on the board (Hypothesis 3); correlations in bold (under the diagonal) pertain to the potential impact of having a woman on the board on subsequent values of Tobin's Q (Hypothesis 4)

$* \mathrm{p}<0.05$. 
In line with the logic proposed by Granger (1969), these analyses suggest that there is feedback or bilateral causality between stock performance and the gender-based composition of company boards. However, as well as assessing support for Hypothesis 3 and Hypothesis 4 separately, it is also possible to gauge the relative support for each by using a binomial test to assess the direction of matched correlations across the diagonal (for a similar logic, see McGarty and Smithson, 2005). From Table 5 we can see that in all cases except one ${ }^{3}$ (i.e. for nine out of ten pairings) the correlation between board composition in year $t$ and Tobin's $Q$ in year $\mathrm{t}+\mathrm{x}$ was greater than the corresponding correlation between Tobin's $Q$ in year $t$ and board composition in year $\mathrm{t}+\mathrm{x} \quad(\mathrm{p}=0.001)$. Accordingly, while both Hypothesis 3 and Hypothesis 4 are supported, there is evidence that the impact of board composition on subsequent values of Tobin's $Q$ was stronger than the impact of Tobin's $Q$ on subsequent board composition.

\section{Discussion}

The purpose of this study was to examine the relationship between the presence of women on the boards of FTSE 100 companies and different measures of company performance. Intriguingly, our findings indicate that this relationship varies as a function of the particular measure of performance one employs. More specifically, in line with Hypothesis 1 and findings recently reported by Adams, Gupta and Leeth (2009), there was no evidence of a relationship between women's presence on the boards of FTSE 100 companies and those companies' accountancybased performance (as measured by ROA and ROE). On these measures, then, there was no evidence either that women are appointed to precarious leadership positions in companies that are failing (i.e. that they are placed on 'glass cliffs' as proposed by Ryan and Haslam, 2005) or that women 'wreak havoc' on company performance (as claimed by Judge, 2003, p. 21).

\footnotetext{
${ }^{3}$ Interestingly, the one exception involved lagged correlations between 2002 and 2003 - data which were the focus of Ryan and Haslam's (2005) 'glass cliff' analysis.
}

However, we noted in the Introduction that the analyses of both Judge and Ryan and Haslam were based on 'subjective' stock-market data rather than 'objective' financial information, and raised the possibility that the inconsistency between these authors' findings and those of Adams and colleagues is a reflection of the different measures on which they were based (see also Ryan and Haslam, 2009). In particular, we argued that, like other forms of prejudice, the bias which underpins women's occupancy of glass cliff positions might relate more to the perceptions of relevant parties (e.g. investors) than to underlying financial reality. Consistent with this suggestion, our analysis supported Hypothesis 2 in revealing consistent evidence of a negative correlation of small to medium size between women's presence on company boards and those companies' stock-market performance (as measured by Tobin's Q). More specifically, companies with at least one woman on their board were valued by investors at $121 \%$ the book value of their assets, while those with all-male boards were valued at $166 \%$ the book value (implying a valuation premium of $37 \%$ for the latter). Our analysis also ruled out the possibility that this pattern was simply a reflection of other company factors that could be associated with women's presence on company boards including board size and number of employees, and the nature of the company's business (whether it was a financial company and whether it was a stereotypically feminine one).

As well as being consistent with findings previously reported by Ryan and Haslam (2005), support for Hypothesis 2 is also consistent with recent work by Lee and James which (using a very similar sample to Adams, Gupta and Leech, 2009) found a negative relationship between the appointment of women to CEO positions in the USA and those companies' subsequent stock-market performance. Lee and James interpret this pattern as a reflection of investors' stereotypic beliefs about women's lack of competence and unsuitability for leadership (see Eagly and Karau, 2002; Schein, 1973) and their scepticism about the leadership abilities and agency of 'outsiders'. These factors seem very likely to be important (e.g. see Kulich, Ryan and Haslam, 2007) but, in addition, it is possible that investors see the presence of women in leadership roles as a signal of organizational crisis and 
potential future decline (in line with glass cliff theorizing) and, as a result, lose confidence in the companies to which they are appointed.

A key question here, then, is whether poor stock performance leads to women's occupancy of leadership roles or whether women's occupancy of leadership roles leads to poor stock performance. The fact that the present study's data related to a five-year period gave us some opportunity to investigate these two hypotheses (Hypothesis 3 and Hypothesis 4, respectively) by examining the time-lagged correlations between board composition and Tobin's Q (following logic and procedures proposed by Granger, 1969). In fact, this analysis supported both hypotheses, providing evidence of feedback or bilateral causality between women's presence on company boards and stock performance.

Nevertheless, support for Hypothesis 4 was appreciably stronger than support for Hypothesis 3. This finding is consistent with the suggestion that investors 'over-interpret' the signals associated with women's presence on company boards - seeing this (incorrectly) as a sign of decline and as a harbinger of ruin. Indeed, if we return again to the observations of Judge (2003) that provided the initial impetus for the present line of research, we can see that these serve as a very vivid illustration of such over-interpretation. That said, it is clearly possible that investors are attuned to sentiments of the form that Judge expresses and are aware that - even though they may have no basis in financial reality - women's presence on company boards is likely to precipitate a fall in company share price and make investment decisions accordingly. In this respect, the general pattern uncovered here accords with models proposed by Bénabou (2008), which reveal the potential for normative beliefs and group dynamics to fuel 'irrational' but nevertheless very powerful stock-market behaviour (in the form of what he terms 'mutually assured delusion', p. 2; see also Akerlof and Kranton, 2005; Akerlof and Shiller, 2009; Haslam et al., 2006; Janis, 1972).

\section{Limitations and future research}

Despite yielding clear patterns of support for our hypotheses and helping to resolve apparent inconsistencies in the literature, the present study is not without its limitations. In particular, while more extensive than previous research (in particular, Ryan and Haslam, 2005), the present analysis is still correlational, and even though time-lagged analyses can provide insights into causality (Granger, 1969) there is no sense in which it establishes this conclusively.

Accordingly, as with previous glass cliff research, there would clearly be value in conducting experimental research to verify the causal pathways specified in our model (i.e. as indicated by the arrows in Figure 2). In particular, the paradigm developed by Haslam and Ryan (2008) to show that organizational crisis leads to the appointment of women leaders could be adapted to test the proposition that the appointment of a woman leader leads perceivers (e.g. investors) to infer that an organization is in crisis and to use this inference as a basis for their decision making. This paradigm could also be a vehicle for ascertaining the importance of this signalling effect relative to other stereotypic inferences (as specified by Lee and James, 2007) in determining reactions to women leaders and investment patterns more generally.

In future research there would also be value in supplementing the present analysis with quantitative and qualitative studies of investor beliefs and behaviour, to see whether the patterns revealed here and by Lee and James (2007) are informed by conscious heuristics and, if so, what the content of these is. In particular, it would be interesting to see (a) whether these are prejudicial (e.g. of the form 'women are bad leaders'; Eagly and Karau, 2002) or outcome-driven (e.g. of the form 'when women occupy leadership roles share prices fall') and (b) whether they are consensually shared and promoted by social influence (Haslam et al., 1998) or derived from investors' idiosyncratic observations and inference. This is important for a number of reasons - most notably in allowing us to assess how and whether these beliefs are likely to change in response to various forms of alternative information.

In this regard it would be interesting too to examine whether exposure to the findings of the present research has any impact on investment behaviour. In particular, will investors invest more in companies that have women on their boards once aware of evidence that such companies are relatively under-valued compared to those that have all-male boards? And will they invest less in companies with all-male boards 


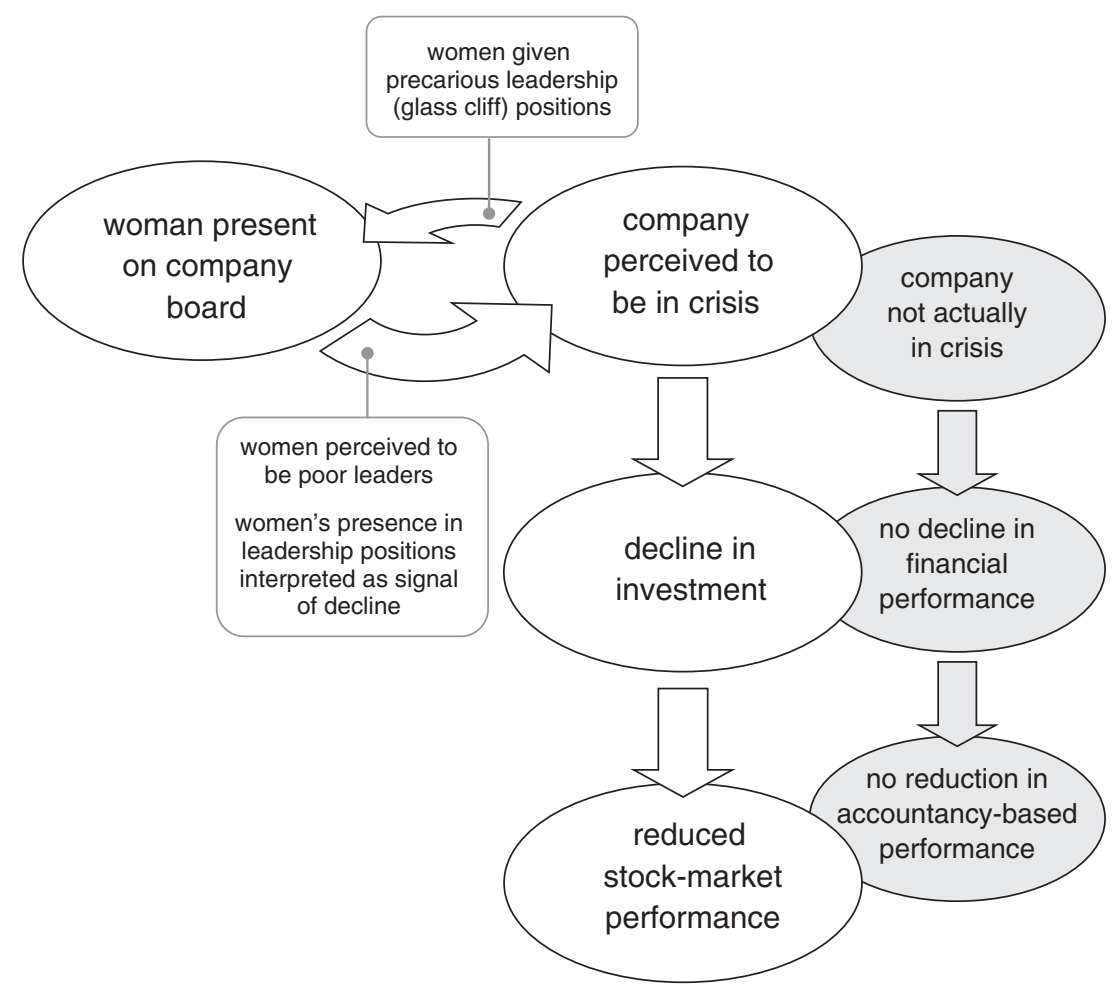

Figure 2. Model of the relationship between women's presence on company boards and company performance as mediated by perceptions of crisis

once aware that such companies are relatively over-valued compared to those that have boards with a woman on them? To the extent that they do either of these things this would tend to suggest that the present findings are not necessarily a manifestation of 'raw' prejudice (e.g. a lack of enthusiasm for companies that have women in leadership roles) and may instead reflect perceived corporate and investment realities (and the more subtle prejudices that underpin such perceptions).

Along related lines, more fine-grained analysis might help establish whether investor behaviour is a response to the presence of women on company boards in general, or whether it is particularly sensitive to the change that is signalled by the appointment of the first woman to a senior position. In the present data there is some suggestion that it is the latter factor that is particularly important as stock performance tended to be more highly correlated with a binary measure of women's presence on company boards than with a measure of the percentage of board members who were women (e.g. see Table 4). This pattern would tend to support Lee and James's (2007) proposition that it is the first women who secure high office who face the brunt of others' prejudice but that this recedes once others follow in their footsteps. Theoretically, we would suggest that whether or not this optimism is warranted depends on a range of factors - not least the behaviour of those women once they assume their leadership positions and the capacity for women who break through the glass ceiling to act collectively to resist discrimination and effect social change (Barreto, Ryan and Schmitt, 2009; Ellemers et al., 2004; Fajak and Haslam, 1998; Hersby, Ryan and Jetten, 2009).

\section{Concluding comment}

Although previous research has tended to imply that the various hypotheses that we have tested in the present research are inconsistent, from a scientific perspective, one very positive feature of the present analysis is that it suggests that this need not be the case. Indeed, as Figure 2 indicates, it is possible to reconcile the above findings and those of previous research in this area within an integrated model of women's 
leadership and company performance. The critical features of this model are (a) that it sees the relationship between women's appointment to leadership positions in companies and those companies' poor stock-market performance as mediated by perceptions of organizational crisis, and (b) that it differentiates between the perceptions that feed into stock-market behaviour and the underlying reality of companies' actual financial performance.

Probing more deeply into the contexts in which people use objective and subjective measures of company performance to make relevant decisions and their reasons for using these different measures would appear to be a fruitful avenue for future inquiry. Similarly, clarifying the ongoing and long-term relationship between market reactions and the realities to which they relate also emerges as an important project for further research and one that is likely to have a number of important practical implications. Yet whatever such research reveals, the point that the present research underlines (and as an abundance of previous research has shown - e.g. Bénabou, 2008; Devers et al., 2007) is that there is no necessary correspondence between company performance and perceived company value, and no requirement that the details of one inform the dynamics of the other. To be a successful investor one does not have to predict how companies will actually perform: one only has to know how other investors will behave. To be discriminated against as a leader one does not actually have to be responsible for poor organizational performance: one only has to be in the firing line when others are taking aim. It is in these dual realities that the full irony of Judge's original analysis resides. For if anyone was 'wreaking havoc' on corporate life in Britain in the early years of this century it was not women leaders but investors.

\section{References}

Adams, S. M., A. Gupta and J. D. Leeth (2009). 'Are female executives over-represented in precarious leadership positions?', British Journal of Management, 20, pp. 1-12.

Akerlof, G. and R. Kranton (2005). 'Identity and the economics of organizations', Journal of Economic Perspectives, 19, pp. 9-32.

Akerlof, G. and R. J. Shiller (2009). Animal Spirits: How Human Psychology Drives the Economy and Why it Matters for Global Capitalism. Princeton, NJ: Princeton University Press.
Allport, G. W. (1954). The Nature of Prejudice. Cambridge, MA: Addison-Wesley.

Ashby, J., M. K. Ryan and S. A. Haslam (2007). 'Legal work and the glass cliff: evidence that women are preferentially selected to lead problematic cases', William and Mary Law Journal, 13, pp. 775-793.

Barberis, N. and R. Thaler (2003). 'A survey of behavioural finance'. In G. M. Constantinides, M. Harris and R. Stulz (eds), Handbook of the Economics of Finance, pp. 1051-1121. Amsterdam: Elsevier Science.

Barreto, M., Ryan, M. K. and Schmitt, M. (eds) (2009). The Glass Ceiling in the 21st Century: Understanding Barriers to Gender Equality. London: APA Division 35 Book Series.

Bénabou, R. (2008) 'Groupthink: collective delusions in organizations and markets'. Working Paper, Princeton University, Princeton, NJ.

Bhojraj, S., C. M. C. Lee and D. K. Oler (2003). 'What's my line? A comparison of industry classification schemes for capital market research', Journal of Accounting Research, 41, pp. 745-774.

Boone, A. L., L. C. Field, J. M. Karpoff and C. G. Raheja (2007). 'The determinants of corporate board size and composition: an empirical analysis', Journal of Financial Economics, 85, pp. 66-101.

Brammer, S., A. Millington and S. Pavelin (2009). 'Corporate reputation and women on the board', British Journal of Management, 20, pp. 17-29.

Branscombe, N. R. (1998). 'Thinking about one's gender group's privileges or disadvantages: consequences for wellbeing in women and men', British Journal of Social Psychology, 37, pp. 167-184.

Bruckmüller, S. and N. R. Branscombe (2007) 'When and why does the glass cliff in leader selection occur? The role of gender stereotypes'. Manuscript submitted for publication, Universities of Erlangen and Kansas.

Burke, R. J. (2000). 'Company size, board size and numbers of women corporate directors'. In R. J. Burke and M. C. Mattis (eds), Women on Corporate Boards of Directors: International Challenges and Opportunities, pp. 157-167. Dordrecht: Kluwer Academic.

Bushman, R. M. and R. J. Indjejikian (1993). 'Accounting income, stock price, and managerial compensation', Journal of Accounting and Economics, 16, pp. 3-23.

Campbell, K. and A. Minguez-Vera (2008). 'Gender diversity in the boardroom and firm financial performance', Journal of Business Ethics, 83, pp. 435-451.

Chan, L. K. C., J. Lakonishok and B. Swaminathan (2007). 'Industry classifications and return comovement', Financial Analysts Journal, 63, pp. 56-70.

Cohen, J. (1977). Statistical Power Analysis for the Behavioral Sciences. New York: Wiley.

Dechow, P. M. and R. G. Sloan (1997). 'Returns to contrarian investment strategies: tests of naïve expectations hypotheses', Journal of Financial Economics, 43, pp. 3-27.

Demsetz, D. and K. Lehn (1985). 'The structure of corporate ownership: causes and consequences', Journal of Political Economy, 93, pp. 1155-1177.

Devers, C. E., A. A. Cannella Jr, G. P. Reilly and M. E. Yoder (2007). 'Executive compensation: a multidisciplinary review of recent developments', Journal of Management, 33, pp. 1016-1072. 
Dwyer, S., O. C. Richard and K. Chadwick (2003). 'Gender diversity in management and firm performance: the influence of growth orientation and organizational culture', Journal of Business Research, 56, pp. 1009-1019.

Eagly, A. H. and S. J. Karau (2002). 'Role congruity theory of prejudice toward female leaders', Psychological Review, 109, pp. 573-598.

Eagly, A. H., M. C. Johannesen-Schmidt and M. van Engen (2003). 'Transformational, transactional and laissez-faire leadership styles: a meta-analysis comparing women and men', Psychological Bulletin, 129, pp. 569-591.

Ellemers, N., H. van den Heuvel, D. De Gilder, A. Maass and A. Bonvini (2004). 'The underrepresentation of women in science: differential commitment or the queen bee syndrome?', British Journal of Social Psychology, 43, pp. 315-338.

Fajak, A. and S. A. Haslam (1998). 'Gender solidarity in hierarchical organizations', British Journal of Social Psychology, 37, pp. 73-94.

Fama, E. F. (1991). 'Efficient capital markets: II', Journal of Finance, 46, pp. 1575-1617.

Gompers, P. A., J. L. Ishii and A. Metrick (2003). 'Corporate governance and equity prices', Quarterly Journal of Economics, 118, pp. 107-155.

Granger, C. W. J. (1969). 'Investigating causal relations by econometric models and cross-spectral methods', Econometrica, 37, pp. 165-190.

Haslam, S. A. and M. K. Ryan (2008). 'The road to the glass cliff: differences in the perceived suitability of men and women for leadership positions in succeeding and failing organizations', Leadership Quarterly, 19, pp. 530-546.

Haslam, S. A., J. C. Turner, P. J. Oakes, K. J. Reynolds, R. A. Eggins, M. Nolan and J. Tweedie (1998). 'When do stereotypes become really consensual? Investigating the group-based dynamics of the consensualization process', European Journal of Social Psychology, 28, pp. 755-776.

Haslam, S. A., M. K. Ryan, T. Postmes, R. Spears, J. Jetten and P. Webley (2006). 'Sticking to our guns: social identity as a basis for the maintenance of commitment to faltering organizational projects', Journal of Organizational Behavior, 27, pp. 607-628.

Hersby, M., M. K. Ryan and J. Jetten (2009). 'Getting together to get ahead: the impact of social structure on women's networking', British Journal of Management, 20, pp.

Higgins, M. C. and R. Gulati (2006). 'Stacking the deck: the effects of top management backgrounds on investor decisions', Strategic Management Journal, 27, pp. 1-25.

Janis, I. L. (1972). Victims of Groupthink. Boston, MA: Houghton-Mifflin.

Judge, E. (2003) 'Women on board: help or hindrance?', The Times, 11 November, p. 21.

Kanter, R. (1977). Men and Women of the Organization. New York: Basic Books.

Kaplan, S. N. and L. Zingales (1997). 'Do investment-cash flow sensitivities provide useful measures of financing constraints?', Quarterly Journal of Economics, 112, pp. 169-215.

Keynes, J. M. (1936). The General Theory of Employment and Money. New York: Harcourt Brace.

Kim, O. and Y. Suh (1993). 'Incentive efficiency of compensation based on accounting and market performance', Journal of Accounting and Economics, 16, pp. 25-53.

Kulich, C., M. K. Ryan and S. A. Haslam (2007). 'Where is the romance for women leaders? The effects of gender on leadership attributions and performance-based pay', Applied Psychology: an International Review, 56, pp. 582-601.

Lee, P. M. and E. H. James (2007). 'She'-e-os: gender effects and investor reactions to the announcement of top executive appointments', Strategic Management Journal, 28, pp. 227241.

McGarty, C. and M. Smithson (2005). 'Independence and nonindependence: a simple test for comparing groups using multiple measures and the binomial test', European Journal of Social Psychology, 35, pp. 171-180.

Morck, R., A. Shleifer and R. Vishny (1988). 'Management ownership and market valuation: an empirical analysis', Journal of Financial Economics, 20, pp. 293-315.

Oakes, P. J., S. A. Haslam and J. C. Turner (1994). Stereotyping and Social Reality. Oxford: Blackwell.

Powell, G. N. and D. A. Butterfield (1994). 'Investigating the glass ceiling phenomenon: an empirical study of actual promotions to top management', Academy of Management Journal, 37, pp. 68-86.

Ryan, M. K. and S. A. Haslam (2005). 'The glass cliff: evidence that women are over-represented in precarious leadership positions', British Journal of Management, 16, pp. 81-90.

Ryan, M. K. and S. A. Haslam (2007). 'The glass cliff: exploring the dynamics surrounding the appointment of women to precarious leadership positions', Academy of Management Review, 32, pp. 549-572.

Ryan, M. K. and S. A. Haslam (2009). 'Glass cliffs are not so easily scaled: on the precariousness of female CEOs' positions', British Journal of Management, 20, pp. 13-16.

Ryan, M. K., S. A. Haslam, M. Hersby and R. Bongiorno (2009). 'Think crisis - think female: glass cliffs and contextual variation in the think manager - think male stereotype', Manuscript under review, University of Exeter.

Schein, V. E. (1973). 'The relationship between sex role stereotypes and requisite management characteristics', Journal of Applied Psychology, 57, pp. 95-105.

Schmitt, M. T., N. R. Branscombe and T. Postmes (2003). 'Women's emotional responses to the perception of pervasive gender discrimination', European Journal of Social Psychology, 33, pp. 297-312.

Singh, V. and S. Vinnicombe (2003). The 2003 Female FTSE Index. Women Pass a Milestone: 101 Directorships on the FTSE 100 Boards. Cranfield: Cranfield School of Management.

Singh, V. and S. Vinnicombe (2005). The 2005 Female FTSE Index. New Look Women Directors Add Value to FTSE 100 Boards. Cranfield: Cranfield School of Management.

Stroh, L. K., J. M. Brett and A. H. Reilly (1996). 'Family structure, glass ceiling, and traditional explanations for the differential rate of turnover of female and male managers', Journal of Vocational Behavior, 49, pp. 99-118.

Tobin, J. (1969). 'A general equilibrium approach to monetary theory', Journal of Money, Credit and Banking, 1, pp. 15-29.

Tosi, H. L., S. Werner, J. P. Katz and L. R. Gomez-Mejia (2000). 'How much does performance matter? A metaanalysis of CEO pay studies', Journal of Management, 26, pp. 301-339.

Trevis Certo, S. (2003). 'Influencing initial public offering investors with prestige: signaling with board structures', Academy of Management Review, 28, pp. 432-446.

Zellner, A. (1979). 'Causality and econometrics'. In K. Brunner and A. H. Meltzer (eds), Carnegie-Rochester Conference Series, Vol. 10, pp. 9-50. Amsterdam: North-Holland. 
Alex Haslam is Professor of Social and Organizational Psychology at the University of Exeter and a former editor of the European Journal of Social Psychology. His work with colleagues focuses on the study of social identity in social and organizational contexts. He is a Fellow of the Canadian Institute for Advanced Research.

Michelle Ryan is an Associate Professor at the University of Exeter, holding a five-year Academic Fellowship from the Research Council of the UK. In 2003 her work on the glass cliff was short-listed for the Times Higher Education Research Project of the Year.

Clara Kulich is an ESRC-funded postdoctoral fellow in the Centre for Leadership Studies at the University of Exeter Business School. Her PhD focused on the gender pay gap, with particular emphasis on the social psychological underpinnings of differences in the executive bonuses awarded to men and women.

Grzegorz Trojanowski is a Lecturer in Finance at the Xfi Centre for Finance and Investment. His academic interests cover areas of corporate finance, corporate governance and the economics of transition. His research topics include executive compensation and turnover, payout policy, and the governance role of shareholders and of company directors.

Cate Atkins is employed as a research assistant on an ESRC-funded grant on 'The individual and the group: advances in social identity'. 